\title{
Methylosphaera hansonii gen. nov., sp. nov., a psychrophilic, group I methanotroph from Antarctic marine-salinity, meromictic lakes
}

\author{
John P. Bowman, ${ }^{1,2}$ Sharee A. McCammon ${ }^{2}$ and Jenny H. Skerratt ${ }^{1,3}$ \\ Author for correspondence: John P. Bowman. Tel: +6136226 2776. Fax: +61362262642. \\ e-mail: john.bowman@antcrc.utas.edu.au
}

1,2 Antarctic $\mathrm{CRC}^{1}$ and Department of Agricultural Science? University of Tasmania, GPO Box 252-80, Hobart, Tasmania 7001, Australia

3 CSIRO Oceanography Division, CSIRO Marine Laboratories, Hobart, Tasmania, Australia

\begin{abstract}
Methanotrophic bacteria were enumerated and isolated from the chemocline and surface sediments of marine-salinity Antarctic meromictic lakes located in the Vestfold Hills, Antarctica (68 ${ }^{\circ} \mathrm{S} 78^{\circ} \mathrm{E}$ ). Most probable number (MPN) analysis indicated that at the chemocline of Ace Lake the methanotroph population made up only a small proportion of the total microbial population and was sharply stratified, with higher populations detected in the surface sediments collected at the edge of Ace Lake and Burton Lake. Methanotrophs were not detected in Pendant Lake. Only a single phenotypic group of methanotrophs was successfully enriched, enumerated and isolated into pure culture from the lake samples. Strains of this group were non-motile, coccoidal in morphology, did not form resting cells, reproduced by constriction, and required seawater for growth. The strains were also psychrophilic, with optimal growth occurring at $10-13^{\circ} \mathrm{C}$ and maximum growth temperatures of 16-21 ${ }^{\circ} \mathrm{C}$. The ribulose monophosphate pathway but not the serine pathway for incorporation of $C_{1}$ compounds was detectable in the strains. The guanine plus cytosine (G+C) content of the genomic DNA was 43-46 mol\%. Whole-cell fatty acid analysis indicated that 16 : $1 \omega 8 \mathrm{c}(37-41 \%), 16: 1 \omega 6 \mathrm{c}(17-19 \%)$, $16: 1 \omega 7 \mathrm{c}(15-19 \%)$ and $16: 0(14-15 \%)$ were the major fatty acids in the strains. 165 rDNA sequence analysis revealed that the strains form a distinct line of descent in the family Methylococcaceae (group I methanotrophs), with the closest relative being the Louisiana Slope methanotrophic mytilid endosymbiont (91.8-92.3\% sequence similarity). On the basis of polyphasic taxonomic characteristics the Antarctic lake isolates represent a novel group I methanotrophic genus with the proposed name Methylosphaera hansonii (type strain ACAM 549).
\end{abstract}

Keywords: methane, methanotrophic bacteria, psychrophilic bacteria, Antarctica, meromictic lakes

\section{INTRODUCTION}

Methanotrophic bacteria have been found to significantly modulate methane flux, acting as a sink for methane, and thus have some relevance to current

Abbreviations: $A O D C$, acridine orange direct counts; MPN, most probable number; NMS, nitrate mineral salts; PLFA, phospholipid fatty acids; RubisCO, ribulose-1,5-bisphosphate carboxylase/oxygenase; sMMO, soluble methane monooxygenase.

The GenBank accession numbers for the 165 rDNA sequences determined in this work are U67929 (ACAM 549) and U77532 (AM11). contentions concerning global climate change and global warming. Most studies of the ecology and activity of methanotrophs have concentrated on freshwater lake and soil communities (Hanson \& Hanson, 1996). More recently a wider range of habitats have been investigated, including groundwater (Bowman et al., 1993a), tundra (Omelchenko et al., 1996), and polar lake environments (Galchenko, 1994). Relatively little is known about the ecology of aerobic methane oxidation in marine systems (Ward et al., 1987), with few marine methanotrophic bacteria having been isolated into pure culture. Only group I methanotrophs have been isolated from marine habitats, including Methylomicrobium pelagicum 
(previously Methylomonas pelagica) isolated from the Sargasso Sea (Sieburth et al., 1987) and Metbylomicrobium-like methanotrophs isolated from Plymouth Sound, United Kingdom (Lees et al., 1991). Clone library and oligonucleotide probing analyses of methane enrichments have detected methanotrophs present in seawater (Holmes et al., 1995). A sodium-requiring methanotroph, Methylobacter marinus, has been characterized extensively (Lidstrom, 1988; Bowman et al., 1993b); however, it appears to be an estuarine-adapted species. Mytilid mussels and pogonophora from hydrocarbon seep and hydrothermal vent areas on the sea floor have been found to contain methanotrophic endosymbionts in their gills (Distel \& Cavanaugh, 1994).

As a preliminary effort to understand the contribution of methanotrophs to methane cycling in the Southern Ocean and Antarctic coastal areas, this study aimed to investigate the methanotrophs that occur in a number of marine-salinity, meromictic lakes. The lakes are located in the Vestfold Hills on the south coast of Prydz Bay in Eastern Antarctica (near the Australian Antarctic station, Davis) and were formed 8000-10000 years ago following the retreat of the polar ice sheet and a subsequent isostatic marine uplift (Adamson \& Pickard, 1986). The lakes range widely in chemical characteristics including salinity, redox potential and temperature. The microbial communities therein are believed to be entirely marine derived (Franzmann \& Dobson, 1993). Some of the Vestfold Hill lakes have been used as model systems for investigating biogeochemical processes occurring in the Southern Ocean and as sources of microbial biodiversity (Ashbolt, 1990). Many geochemical studies have focused on Ace Lake, which has approximately marine salinity $(30 \%)$ at its chemocline $(10-11 \mathrm{~m}$ depth) and increasing to $37-42 \%$ in its extensive anoxic zone (12 m-24 m depth) (Franzmann et al., 1987, 1991; Gibson et al., 1991). Ace Lake is completely ice-covered nearly all-year round and is highly stable. The microbial community structure and biomass levels have been previously investigated in Ace Lake through the use of phospholipid fatty acid (PLFA) profiling (Mancuso et al., 1991), with the detection of methanogen-derived ether-linked phospholipids. A relatively low level of methanogenesis was also found to occur in Ace Lake (Franzmann et al., 1991). Subsequently, a psychrotolerant methanogen, Methanococcoides burtonii, isolated from sediments of Ace Lake was characterized (Franzmann et al., 1992). Methane approaches saturation $(\sim 5 \mathrm{mM})$ at the bottom of Ace Lake (20-24 m depth) and most methane is removed through anaerobic methane oxidation (or possibly ebullition) before it reaches the oxycline (Franzmann et al., 1991).

In this study we report that methanotrophs are present in the water columns and sediments of marine-salinity Antarctic meromictic lakes and have an ecophysiology particularly well-suited to the lake habitats. The Antarctic methanotrophs subsequently isolated and characterized represent a novel group I methanotroph, Methylosphaera hansonii, gen. nov., sp. nov.

\section{METHODS}

Sampling. Duplicate water and shore edge sediment samples were collected from four meromictic lakes in the Vestfold Hills area, Eastern Antarctica $\left(68^{\circ} \mathrm{S} 78^{\circ} \mathrm{E}\right)$ during November 1995. Water was collected from Ace Lake from depths of 4, 8, $10,11,12,13,14,16$ and $23 \mathrm{~m}$ and from Pendant Lake at depths of $3,6,9$ and $12 \mathrm{~m}$. Water was collected from the chemocline of Burton Lake $(11 \mathrm{~m})$. Water samples were collected using 2 litre Kemmerer bottles through $20-30 \mathrm{~cm}$ holes drilled through the lake ice covers. Kemmerer bottles are enclosed hollow tubes with a valve. The bottle is lowered into the water column and the designated depth is reached by timing the descent of the bottle. A signal then causes the valve to open and the bottle is filled with water from that depth. Thus the accuracy of sampling is dependent on the timing of the descent. Two samples were collected from each depth. Sediment was collected from the edges of Ace Lake and Burton Lake where the water depth was $10-30 \mathrm{~cm}$. Samples were then transported promptly to the laboratory at Davis station. Portions of samples were fixed by the addition of $2 \%$ glutaraldehyde and stored at $4{ }^{\circ} \mathrm{C}$ for further analysis. A portion of the water samples (vol. $250 \mathrm{ml}$ ) was filtered through a $0.22 \mu \mathrm{m}$ polycarbonate filter. The filtered material was then resuspended in $2.5 \mathrm{ml}$ artificial seawater and used in most probable number (MPN) counting experiments. Sediment samples were allowed to settle and the liquid layer removed. Approximately $1 \mathrm{~g}$ wet sediment was added to $10 \mathrm{ml}$ artificial seawater to create a sediment slurry.

Enrichment and isolation of methanotrophs. Water samples (unfiltered, $1 \mathrm{ml}$ ) and sediment samples $(1 \mathrm{ml})$ were added directly to $20 \mathrm{ml}$ nitrate mineral salts (NMS) medium (Bowman et al., 1993a) in $60 \mathrm{ml}$ serum vials (Wheaton). The NMS medium was prepared in different strengths of seawater using 'Ocean Nature' artificial seawater salts (Aquasonic). Seawater strengths used were $0 \%, 20 \%, 50 \%, 100 \%$ and $200 \%$. The NMS medium was also supplemented with a vitamin solution (Balch \& Wolfe, 1976). Serum vials were closed with butyl rubber caps and with aluminium crimped seals, after which high-purity methane (BOC Gases) was added to achieve a $15-20 \%(\mathrm{v} / \mathrm{v})$ atmospheric concentration. In some enrichments $\mathrm{CO}_{2}$ was also added for a final atmospheric concentration of $3-5 \%(v / v)$ while in other cases the air in the vials was replaced by nitrogen, before the addition of methane, to achieve a lower level of oxygen (1-3\%). The vials were then incubated at $4{ }^{\circ} \mathrm{C}$ for up to 3 months. In most cases positive enrichments were obtained after $4-6$ weeks incubation. The majority of isolates, including ACAM 549, were isolated from enrichments which contained NMS medium prepared with full-strength artificial seawater. Turbid enrichment cultures were transferred to fresh NMS/seawater medium in 96-well titre trays for purification. The enrichment cultures were serially diluted in fivefold steps and the titre trays incubated in anaerobic jars (Oxoid) into which methane was forced to achieve an atmosphere containing 30-50\% (v/v) methane. Growth in the wells at the highest dilution was examined by oil immersion light microscopy to ascertain purity and was subsequently transferred to fresh serum vials if found to consist of single uniform morphology. This process was repeated when necessary. Following purification the isolates were maintained in NMS medium with full-strength seawater under $1: 1$ air $/$ methane at $2{ }^{\circ} \mathrm{C}$. The isolates were also cyropreserved as suspensions in NMS prepared with artificial seawater and $20 \%(\mathrm{v} / \mathrm{v})$ glycerol and stored at $-80^{\circ} \mathrm{C}$.

Enumeration procedures. Acridine orange direct counts (AODC) were determined from glutaraldehyde-fixed samples. 
The samples were diluted in artificial seawater and treated with $0.01 \%$ acridine orange in $0.2 \mathrm{M}$ acetate buffer at $\mathrm{pH} 4.5$. The samples were incubated in the dark for $5 \mathrm{~min}$, filtered through a $0.2 \mu \mathrm{m}, 47 \mathrm{~mm}$, black polycarbonate filter (Millipore) and then washed with filtered artificial seawater to remove excess stain. The filters were examined under oil immersion with a coverslip using a Leitz DMA microscope. Cells were counted in approximately 20 random fields for each sample dilution. MPN counting was done with samples which were prepared as for the methanotroph strain purification procedure except that the filter-concentrated water column samples and sediment slurries were initially diluted $1: 10$ in the first well and then serially diluted in fourfold steps. Using the row of 12 wells in the 96-well titre trays a maximum dilution of $4.2 \times 10^{-7}$ was achieved and five replicates were used for each sample. MPN trays were incubated at $2{ }^{\circ} \mathrm{C}$ and $25^{\circ} \mathrm{C}$ for up to 3 months. Cell numbers were determined using the BASIC computer program (via Quick Basic) for MPN determination described by Koch (1994) based on five replicates.

Phenotypic characterization. The isolated strains were characterized by carbon and nitrogen source tests and enzyme assays which have been previously described (Bowman et al., 1993b). NMS medium prepared with artificial seawater was used as the basal medium for the phenotypic tests and incubations were carried out at $10^{\circ} \mathrm{C}$. In addition the enzyme profiles of strains were examined using API-ZYM test strips (VitekBioMerieux) which were prepared and examined according to the manufacturer's instructions except that they were incubated at $10^{\circ} \mathrm{C}$ with artificial seawater as the suspending fluid. Seawater requirement was tested by adding artificial seawater salts at different levels (from 0 to $200 \%$ strength). The naphthalene oxidation assay of Brusseau et al. (1992) was used to detect putative presence of soluble methane monooxygenase (sMMO) activity. Isolates were grown in NMS/ seawater medium prepared carefully to be as free from copper ions as possible. Copper ions suppress sMMO activity (Brusseau et al., 1992). The acetylene reduction assay (Takeda, 1988) was used to detect nitrogen fixation in cells cultivated in nitrogen-free medium.

Whole-cell fatty acid analysis. Cells were cultivated statically in 2-litre flasks at $10^{\circ} \mathrm{C}$ for $14 \mathrm{~d}$ and then centrifuged and washed in artificial seawater. The pellets were lyophilized using a vacuum freeze-drier prior to solvent extraction. The whole-cell fatty acid profiles were quantitatively determined using gas chromatography-mass spectrometry (GC-MS) procedures (Nichols et al., 1993). The geometry and position of double bonds in monounsaturated fatty acids were confirmed using dimethyldisulfide derivatization and analysis using GC-MS (Nichols et al., 1986). The double bond positions are numbered from the methyl $(\omega)$ end of the fatty acid.

Genotypic analysis. Genomic DNA was extracted and purified from cells using the procedure of Marmur \& Doty (1962). The DNA $\mathrm{G}+\mathrm{C}$ content was then determined from thermal denaturation profiles (Sly et al., 1986) using a GBC 916 spectrophotometer fitted with a thermoprogrammer. Genomic DNA was sheared to an average size of $1 \mathrm{~kb}$ using sonication and used in DNA:DNA hybridization experiments. Hybridization was performed in $2 \times \mathrm{SSC}$ buffer $(0.3 \mathrm{M} \mathrm{NaCl}$, $0.03 \mathrm{M}$ sodium citrate, $\mathrm{pH} 7.0$ ) at an optimal renaturation temperature of $73^{\circ} \mathrm{C}$ (Huss et al., 1983).

Phylogenetic analysis. The $16 \mathrm{~S}$ rDNA genes from strains ACAM 549 and AM11 were amplified by PCR using primers 27fM13f (5'-TGTAAAACGACGGCCAGTAGAGTTTGATCCTGGCTCAG-3') and 1492rM13r (5'-TACGGYTACCTTGTTACGACTTCAGGAAACAGCTATGACC-3') in which -21 M13 forward and M13 reverse sites were combined with 9-27f and 1492-1512r 16S rDNA primers, respectively. The conditions for the PCR have been described by Dobson et al. (1993). The amplicons were purified using the QIAquick PCR purification kit (Qiagen). The 16S rDNA sequences were then generated using dye primer cycle sequencing ready reaction $-21 \mathrm{M} 13$ forward and M13 reverse kits and an A3738 automated DNA sequencer (Applied Biosystems) according to protocols provided by the manufacturer. The sequence was then manually aligned to other methanotroph $16 \mathrm{~S}$ rDNA sequences and relatives obtained from the GenBank nucleotide database. Software from Phylip (phylogenetic inference program package) v. 3.57c (Felsenstein, 1993) was used to further analyse the sequence data set. DNADIST was used to determine sequence similarities and NEIGHBOR to create a phylogenetic tree. With the programs SEQBOOT and CONSENSE, bootstrap analysis using 1000 replicates was used to calculate the branching proportions within the phylogenetic tree. Outgroup $16 \mathrm{~S}$ rDNA sequences and their respective GenBank accession number used in the analysis included the following: Cardiobacterium hominis M35014, Chromatium vinosum M26629, Coxiella burnetii M21291, Cycloclasticus pugetii L34955, Ectothiorhodospira halophila M26630, Legionella pneumophila X73402, Louisiana Slope methanotroph endosymbiont U05595, Methylobacter whittenburyi X72773, Metbylococcus capsulatus X72770, Metbylomicrobium pelagicum X72775, Methylomonas methanica L20840, Methylophaga marina X95459, Oceanospirillum linum M22365 and Thiothrix nivea L40993.

\section{RESULTS}

\section{Enrichment and isolation of methanotrophs}

Serum vials incubated at $4{ }^{\circ} \mathrm{C}$ containing NMS medium with full-strength and in some occasions half-strength seawater were the only successful enrichments. Enrichments of methanotrophs occurred in the absence of vitamins, while increasing the partial pressure of $\mathrm{CO}_{2}$ to $3-5 \%$ and/or lowering the oxygen level $(1-3 \%)$ had no discernible effect on the success rate of enrichments. No isolates were obtained from the Pendant Lake water samples. Successful enrichments uniformly displayed a white turbidity which mostly sedimented. Microscopic examination of the enrichments showed the presence of non-motile spherical cells along with motile, slender rod-like cells. Attempts to culture the spherical cells on solid media made with technical-grade agar (DavisGelatine) failed, a phenomenon observed previously for some other marine methanotroph enrichments (Lees et al., 1991). Lower concentrations $(0 \cdot 2-0 \cdot 6 \%)$ of various highly purified agars including agar noble and agarose as well as gelrite (Phytagel, Sigma) were likewise unsuccessful. Serial dilution in titre trays was used for obtaining pure cultures of the spherical morphotype, with microscopic checks to confirm purity. All subsequent experiments with the methanotroph isolates were performed in NMS liquid medium prepared with $100 \%$ strength seawater salts. The rod-like organisms found in the enrichments grew well on NMS medium containing methanol but did not grow on methane, while a variety of colony types developed on marine 2216 agar (Difco), indicating that the rods were methylo- 
Table 1. Population results for Antarctic meromictic lake samples and genotypic results for sample isolates

\begin{tabular}{|c|c|c|c|c|c|c|}
\hline \multirow[t]{2}{*}{ Sample site ${ }^{*}$} & \multirow{2}{*}{$\begin{array}{l}\text { Depth } \\
(\mathrm{m})\end{array}$} & \multicolumn{2}{|c|}{ No. of cells $1^{-1}$ detected by: } & \multirow[t]{2}{*}{ Isolate no. } & \multirow{2}{*}{$\begin{array}{c}\mathrm{G}+\mathrm{C}(\mathrm{mol} \%) \\
\left(\boldsymbol{T}_{\mathrm{m}}\right)\end{array}$} & \multirow{2}{*}{$\begin{array}{c}\text { DNA homology } \\
\text { with ACAM } 549 \\
(\%)\end{array}$} \\
\hline & & AODC & $\mathrm{CH}_{4}-\mathrm{MPN}$ & & & \\
\hline Ace Lake & 4 & $1.7 \times 10^{8}$ & ND & - & - & - \\
\hline Ace Lake & 8 & $2 \cdot 2 \times 10^{8}$ & ND & - & - & - \\
\hline Ace Lake & 10 & $4.3 \times 10^{8}$ & $4.0 \times 10^{2}$ & AM2 & $44 \cdot 2$ & 70 \\
\hline Ace Lake & 11 & $6.2 \times 10^{8}$ & $3.6 \times 10^{5}$ & AM4 & $43 \cdot 5$ & 65 \\
\hline Ace Lake & 12 & $5 \cdot 9 \times 10^{8}$ & $2.6 \times 10^{3}$ & ACAM 549 & $44 \cdot 8$ & 100 \\
\hline Ace Lake & 13 & $6.3 \times 10^{8}$ & $1.0 \times 10^{3}$ & AM7 & $45 \cdot 0$ & 81 \\
\hline Ace Lake & 14 & $7 \cdot 1 \times 10^{8}$ & ND & AM8 & $44 \cdot 2$ & 84 \\
\hline Ace Lake & 16 & $9.8 \times 10^{8}$ & ND & - & - & - \\
\hline Ace Lake & 23 & $1.5 \times 10^{9}$ & ND & - & - & - \\
\hline Ace Lake (sediment) & - & $8.7 \times 10^{8} \dagger$ & $1.6 \times 10^{6} \dagger$ & AM10 & $44 \cdot 4$ & 79 \\
\hline Burton Lake & 11 & $5 \cdot 2 \times 10^{8}$ & $4 \cdot 1 \times 10^{4}$ & AM11 & $45 \cdot 9$ & 86 \\
\hline Burton Lake (sediment) & - & $7.5 \times 10^{8} \dagger$ & $4.0 \times 10^{6} \dagger$ & AM12 & $44 \cdot 5$ & 92 \\
\hline
\end{tabular}

ND, Methanotrophs not detected with MPN analysis.

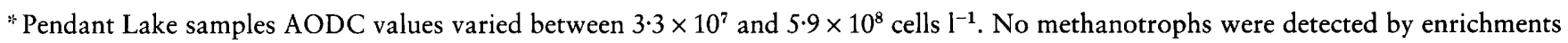
or by MPN analysis.

†For sediment samples population estimates are per g sediment.

trophic and heterotrophic co-contaminants. During the enrichment of sediment (using NMS with full-strength artificial seawater) from the edge of Burton Lake, a yellow-orange pellicle in the enrichment culture appeared after approximately 2 weeks incubation. Rodshaped, sluggishly motile, bacterial cells associated with the pellicle did not grow on transfer to fresh media nor did they reappear upon an attempted re-enrichment of the sediment sample during the MPN analyses or on any solidified media. It could not be confirmed if this organism was a true methanotroph. Eight methanotrophic strains with the spherical morphotype were successfully purified from waters and sediments of Ace Lake and Burton lake (Table 1).

\section{Enumeration of methanotrophs in meromictic lake samples}

AODC results and MPN counts of viable methanotrophs are shown in Table 1. MPN values are based on counts from titre trays incubated at $2{ }^{\circ} \mathrm{C}$ and using NMS medium prepared with full-strength seawater salts. No growth was obtained in enrichments or titre trays with NMS made with 0 or $20 \%$ strength seawater salts while substantially lower populations were obtained with NMS prepared with $50 \%$ and $200 \%$ strength seawater salts. Additionally the methanotrophs enriched were clearly psychrophilic, as titre trays incubated at $20-25^{\circ} \mathrm{C}$ showed no signs of growth for any of the NMS medium variants utilized. The inclusion of vitamins growth factors had no stimulatory effect on the MPN population values.

The methanotroph population in Ace Lake peaked at $11 \mathrm{~m}$ depth, which corresponded to the chemocline where methane and oxygen were depleted (Fig. 1) and the salinity was $30 \%$. At this depth the methanotroph population constituted approximately $0.06 \%$ of the total microbial population, as determined from the proportion of the methanotroph MPN value at $11 \mathrm{~m}$ versus the AODC value. Below $11 \mathrm{~m}$ depth the measurable mechanotroph population fell off sharply, while at 4 and $8 \mathrm{~m}$ methanotrophs were undetectable. Cell densities in surface sediment samples collected at the edges of Ace Lake and Burton Lake were higher than that found for the peak population in the Ace Lake water column, ranging from $1.6 \times 10^{6}$ to $4.0 \times 10^{6}$ cells per g sediment (Table 1$)$.

\section{Phenotypic characteristics of the methanotrophic isolates}

The methanotroph isolates were found to have a very similar morphology, forming non-motile, spherical cells, $1.5-2.0 \mu \mathrm{m}$ in diameter (Fig. 2). No cysts or cyst-like cells were detected after application of the staining procedure of Vela \& Wyss (1964) and the cells were non-refractile regardless of the age of the culture. The strains were not heat resistant (survival at $80^{\circ} \mathrm{C}$ for $20 \mathrm{~min}$ ) and did not form exospores. The isolates grew well at $0{ }^{\circ} \mathrm{C}$, grew optimally at $10-13^{\circ} \mathrm{C}$, and had maximum growth temperatures in the range of $16-21^{\circ} \mathrm{C}$. The generation time of ACAM 549 at its optimal temperature for growth of about $12^{\circ} \mathrm{C}$ was determined to be $19 \cdot 0 \mathrm{~h}$. The strains required seawater for growth, a requirement that could not be substituted by adding $\mathrm{NaCl}$ alone. The best growth was found to occur at $70-100 \%$ seawater; at below $50 \%$ seawater, growth yields declined dramatically. Vitamins were not required for growth and the carbon substrate utilization range was limited to methane and methanol, which is typical for most obligate 


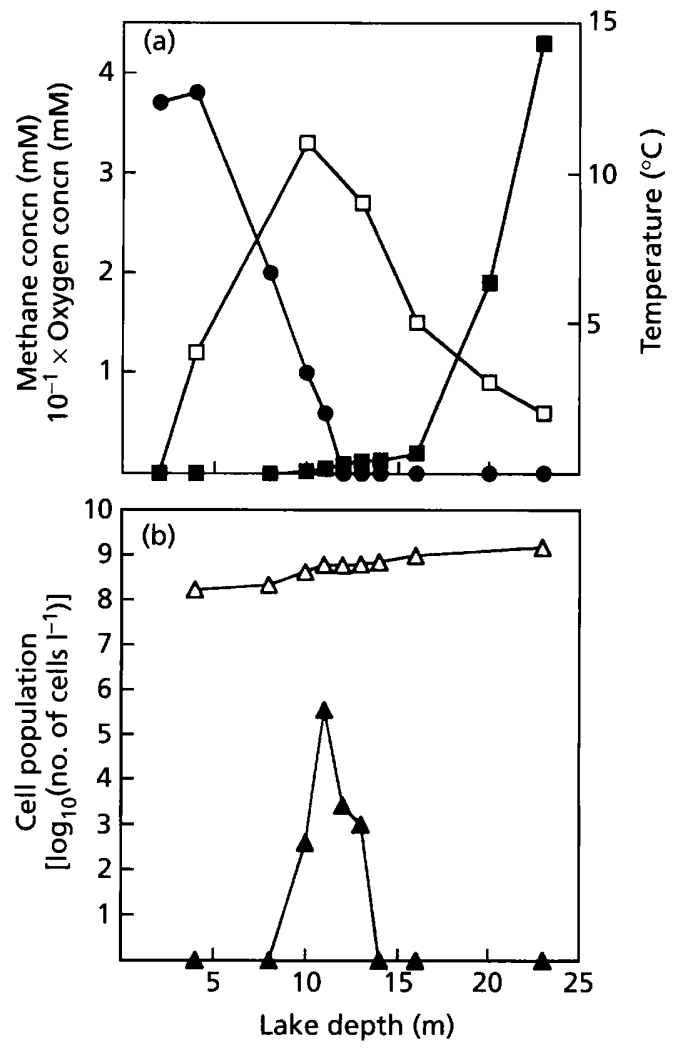

Fig. 1. (a) Profiles of concentrations of oxygen (O), methane $(\square)$, and temperature ( $\square$ ) across the depth profile of Ace Lake. Chemical data are from Franzmann et al. (1991) determined in December, 1987. (b) AODC $(\triangle)$ and methanotroph MPN counts (A) across the depth profile of Ace Lake.

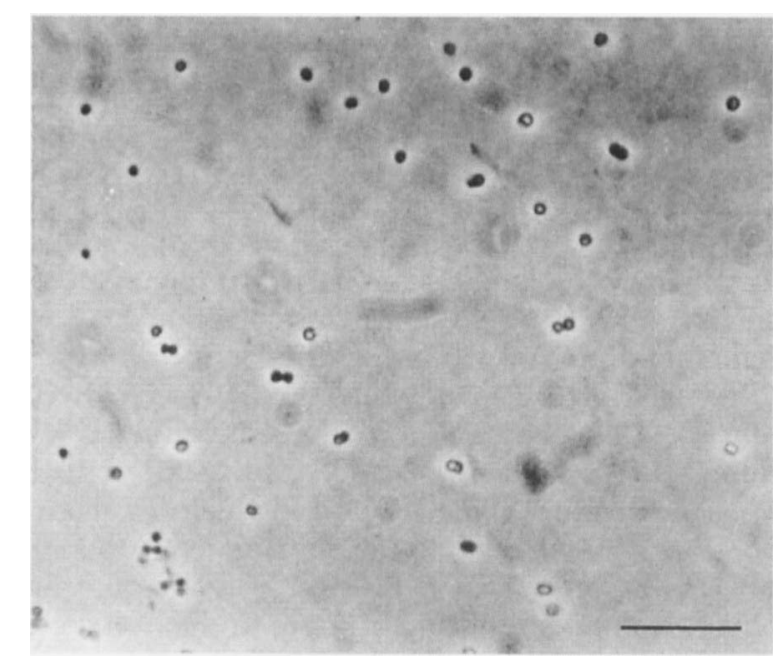

Fig. 2. Phase-contrast photomicrograph of isolate ACAM 549 grown in NMS/seawater medium at $10^{\circ} \mathrm{C}$ for $10 \mathrm{~d}$. Bar, $5 \mu \mathrm{m}$.

methanotrophic bacteria. Atmospheric nitrogen was found to be fixed when strains were cultivated in nitrogen-free mineral salts/seawater media. This was confirmed by testing cell suspensions with the acetylene reduction technique (Takeda, 1988). Under nitrogenfixing conditions growth yields fell to $40-50 \%$ of levels found for growth with nitrate and ammonia. Of the various sources of organic nitrogen tested, the Antarctic isolates could only use L-glutamine (which was also stimulatory to growth) as a sole source of nitrogen. Slight growth was also detected when $0.05 \%$ yeast extract or $0.05 \%$ Casamino acids was supplied as nitrogen source; however, above concentrations of $0.25 \%$ these reagents inhibited growth. The isolates were able to reduce nitrate to nitrite, although no growth occurred anaerobically with methane or methanol as the carbon source. The strains formed a phosphohydrolase detected through use of the API ZYM test strips; catalase and cytochrome- $c$ oxidase activities were also detected. When cells were incubated under copper-free conditions, to promote sMMO synthesis, the growth yields fell to approximately one-third of the control, which contained $0 \cdot 25 \mu \mathrm{m}$ copper sulfate. The naphthalene oxidation test did not detect the presence of sMMO in any of the strains grown under copper-free conditions. The strains all formed hexulose phosphate synthase, which is the key enzyme of the ribulose monophosphate pathway for the incorporation of $\mathrm{C}_{1}$ compounds and is found in group I methanotrophs. Hydroxypyruvate reductase, the key enzyme of the serine pathway for $\mathrm{C}_{1}$ compound incorporation and found in group II methanotrophs, could not be detected. Ribulose-1,5-bisphosphate carboxylase/oxygenase (RubisCO), urease, and alkaline phosphatase activity were also not detected in any of the strains.

\section{Fatty acid composition, genotype and phylogeny of the methanotrophic isolates}

The whole-cell fatty acid composition was determined for three methanotrophic isolates (AM4, ACAM 549 and AM11) by GC and GC-MS techniques. The three strains possessed highly similar fatty acid profiles (Table 2) and could be readily differentiated from other group I methanotrophs on the basis of fatty acid composition, as they characteristically contained high levels of the fatty acid $16: 1 \omega 8 \mathrm{c}$ but lacked significant levels of $16: 1 \omega 5 \mathrm{c}, 16: 1 \omega 5 \mathrm{t}$ or $14: 0$. The other major fatty acids found in the Antarctic strains included 16:1 $166 \mathrm{c}$, $16: 1 \omega 7 \mathrm{c}$ and $16: 0$ (Table 2).

The DNA G $+\mathrm{C}$ content of the Antarctic strains ranged from 43.5 to $45.9 \mathrm{~mol} \%$ (Table 1). DNA:DNA hybridization analysis indicated that all the isolates were closely related to each other, with DNA homology values ranging from 65 to $92 \%$ (Table 1 ).

The near complete $16 \mathrm{~S}$ rDNA sequence of methanotroph strains ACAM 549 and AM11 were determined in this study. The sequences were about $1450 \mathrm{bp}$ in length and stretched from nucleotide positions 20 to 1475 (E. coli numbering). Analysis of the sequence data by Phylip (v. $3.57 \mathrm{c}$ ) software indicated the strains formed a distinct line of descent within the family Methylococcaceae (Bowman et al., 1995) in the gamma subdivision of the 
Table 2. Whole-cell fatty acid composition of the Antarctic methanotrophic isolates and group I methanotrophic genera

Fatty acid data for the group I methanotroph genera are from Bowman et al. (1993b).

\begin{tabular}{|c|c|c|c|c|c|}
\hline \multirow[t]{2}{*}{ Fatty acid } & \multicolumn{5}{|c|}{ Fatty acid composition ( $\%$ range $)$} \\
\hline & Antarctic strains & Methylomonas & Methylomicrobium & Methylobacter & Methylococcus \\
\hline $14: 0$ & $2-3$ & $19-25$ & $1-2$ & $7-10$ & $1-6$ \\
\hline i15:0 & - & $0-2$ & $0-7$ & $0-\operatorname{tr}$ & $0-1$ \\
\hline a15:0 & - & $0-2$ & - & - & $0-1$ \\
\hline $15: 0$ & $1-2$ & $0-1$ & - & $0-4$ & $0-13$ \\
\hline $16: 1 \omega 8 \mathrm{c}$ & $37-41$ & $19-41$ & $12-19$ & - & - \\
\hline $16: 1 \omega 7 \mathrm{c}$ & $16-19$ & $8-15$ & $14-20$ & $56-58$ & $11-46$ \\
\hline $16: 1 \omega 7 \mathrm{t}$ & $2-3$ & - & - & - & $0-2$ \\
\hline $16: 1 \omega 6 \mathrm{c}$ & $17-18$ & $5-13$ & $6-14$ & $4-5$ & $0-12$ \\
\hline $16: 1 \omega 5 \mathrm{c}$ & $0-\operatorname{tr}$ & $2-6$ & $6-7$ & $6-8$ & $0-9$ \\
\hline $16: 1 \omega 5 \mathrm{t}$ & - & $8-17$ & $6-28$ & $10-11$ & $0-6$ \\
\hline $16: 0$ & $14-15$ & $4-9$ & $11-18$ & $8-9$ & $34-56$ \\
\hline $17: 1 \omega 8 \mathrm{c}$ & $\operatorname{tr}-1$ & - & - & - & $0-\operatorname{tr}$ \\
\hline $17: 1 \omega 7 \mathrm{c}$ & $\operatorname{tr}-1$ & $0-1$ & - & - & $0-2$ \\
\hline cy17:0 & - & $0-2$ & - & - & $0-15$ \\
\hline $18: 1 \omega 9 \mathrm{c}$ & $0-1$ & $0-\mathrm{tr}$ & - & - & $0-3$ \\
\hline $18: 1 \omega 7 \mathrm{c}$ & $1-2$ & tr -2 & $0-26$ & $1-3$ & $0-6$ \\
\hline $18: 0$ & $\operatorname{tr}$ & $0-\operatorname{tr}$ & $0-3$ & - & $0-2$ \\
\hline cy19:0 & - & $0-\operatorname{tr}$ & - & - & $0-3$ \\
\hline
\end{tabular}

tr, Trace amount $(<0.1 \%)$ of fatty acid.

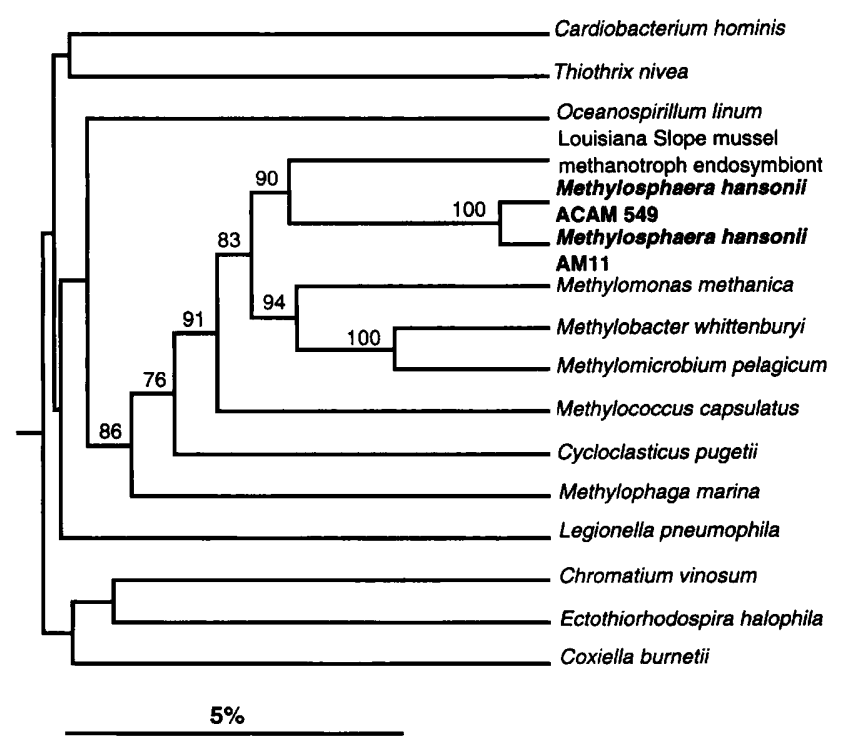

Fig. 3. Phylogenetic tree showing the relationship of Methylosphaera hansonii ACAM 549 and AM11 to other members of the family Methylococcaceae and related genera of the gamma subdivision of the Proteobacteria. Numbers are the bootstrap proportions (\%) for each branch point in the tree. Bar, sequence dissimilarity value of $5 \%$.

Proteobacteria (Fig. 3). The closest relative to the Antarctic strains was the Louisiana Slope methanotroph mytilid endosymbiont with a similarity of $91 \cdot 8-92 \cdot 3 \%$.
Other members of the Methylococcaceae, including species of the genera Methylobacter, Methylococcus, Methylomicrobium and Methylomonas, have a similarity of $90 \cdot 2-91 \cdot 3 \%$ to ACAM 549 and AM11. Bootstrap analysis showed a significant probability of association of ACAM 549 with the methanotroph endosymbiont of $90 \%$ (Fig. 3).

\section{DISCUSSION}

PLFA profiling has been used to detect populations of methanotrophs, taking advantage of characteristic lipid biomarkers such as $16: 1 \omega 8 \mathrm{c}, 16: 1 \omega 5 \mathrm{t}$ and $18: 1 \omega 8 \mathrm{c}$, which some methanotrophs synthesize (Nichols et al., 1985; Guezennec \& Fiala-Medioni, 1996). However, analyses of PLFA biomarkers in the sediments and water column of Ace Lake (Mancuso et al., 1991) failed to detect the presence of $16: 1 \omega 8 \mathrm{c}$, which is the predominating lipid in methanotrophs isolated in this study (Table 2), or any other methanotroph signature lipid. Methanotroph population estimates in the chemoclines of Ace and Burton Lakes were three orders of magnitude lower than was found for populations of methanotrophs detected in the lakes of the Bunger Hills, Antarctica (Galchenko, 1994). Methanotroph populations in the inshore sediment of the meromictic lakes sampled were 4-10 times higher than the peak populations detected at the chemocline of Ace Lake. Overall, methanotrophs make up a relatively small proportion $(<0 \cdot 1-1 \%)$ of the total microbial community in the meromictic lakes 
Antarctic methanotrophic bacteria

Table 3. Differentiation of Methylosphaera hansonii gen. nov., sp. nov. from other group I methanotrophic genera

\begin{tabular}{|c|c|c|c|c|c|}
\hline Characteristic & $\begin{array}{c}\text { Methylosphaera } \\
\text { hansonii } \\
\text { sp. nov., gen. nov. }\end{array}$ & Methylomonas & Methylomicrobium & Methylobacter & Methylococcus \\
\hline Cell morphology & $\operatorname{cocci}$ & rods & rods & cocci or rods & cocci or rods \\
\hline Motility & - & + & + & $\mathbf{v}$ & - \\
\hline Cyst formation & - & + & - & + & + \\
\hline Carotenoids & - & + & - & - & - \\
\hline Growth at $25^{\circ} \mathrm{C}$ & - & + & + & + & $\mathrm{v}$ \\
\hline Growth at $45^{\circ} \mathrm{C}$ & - & - & - & - & + \\
\hline Requires seawater & + & - & $\mathbf{v}$ & $*$ & - \\
\hline RubisCO & - & - & - & - & + \\
\hline Nitrogen fixation & + & $\mathrm{v}$ & - & - & + \\
\hline Mol\% G $+\mathrm{C}\left(T_{\mathrm{m}}\right)$ & $43-46$ & $51-59$ & $50-60$ & $49-54$ & $59-66$ \\
\hline
\end{tabular}

+ , Trait present; - , trait absent; $v$, varies between strains.

* Methylobacter marinus requires tapwater and approximately $0 \cdot 1 \mathrm{M} \mathrm{NaCl}$ for growth.

examined in this study and below a level normally detectable by PLFA profiling.

The slow input of organic matter into Ace Lake and its relatively low temperature has resulted in low methane production rates $\left(<2.5 \mu \mathrm{mol} \mathrm{kg}^{-1} \mathrm{~d}^{-1}\right)$ and methane concentrations approach detection limits in the chemocline (Franzmann et al., 1991). Though very little methane diffuses into the oxic zone of Ace Lake a methanotroph population is still sustained (Fig. 1). Bunger Hill lakes, in particular Polyanskii Lake and Transcription Bay, have much higher sediment and water column methanogenesis rates (Galchenko, 1994) than Ace Lake and these lakes also have higher methanotroph populations, which include both group I and II methanotrophs. Thus the successful isolation of only a single phenotype from the water column and shore edge sediment samples was slightly unexpected, especially with the surface sediment samples. In these sediment samples it was thought anaerobic methane oxidation would be diminished by the shallowness of the water layer and a greater amount of methane should have been available at the sediment surface for methanotrophic growth. This was confirmed by the higher populations of methanotrophs which were enumerated in the sediment samples (Table 1). However, only the spherical methanotroph morphotype was successfully isolated from these samples. The presence of other methanotrophs cannot, however, be discounted, as indicated by the appearance of a yellow-pigmented cell mass in the enrichment of the Burton Lake sediment sample which has so far defied cultivation. The inability to culture any of the positive methane enrichments on solid media made it very difficult to determine if more than one type of methanotroph was indeed present. Microscopic examination of the enrichments and lower MPN dilutions also failed to find tangible evidence of the presence of any other cellular morphotype possibly belonging to a methanotroph other than the sphericalshaped morphotype.
Polyphasic taxonomic analysis of the methanotrophic isolates indicates that they are group I methanotrophs forming a single coherent phenotypic and genotypic group. The Antarctic isolates have an ecophysiology well suited to the marine salinity meromictic lake habitat of Ace and Burton Lakes. The isolates grew optimally with seawater salinity levels and were psychrophilic, growing optimally at temperatures only slightly higher than the summertime in situ temperatures of Ace Lake (Fig. 1). The combination of psychrophilic growth and seawater requirements appears to be a frequent combination and has been observed in virtually all psychrophilic bacterial strains characterized from sympagic habitats (J. P. Bowman \& D. S. Nichols, unpublished). Psychrophilic methanotrophs have also been isolated from tundra soil; however, these strains did not require seawater and have been classified as a species of the genus Metbylobacter (Omelchenko et al., 1996). The Antarctic isolates were able to fix nitrogen under atmospheric oxygen levels. Nitrogen fixation in the group I methanotrophs of the genus Methylococcus has been previously found to be oxygen sensitive (Murrell \& Dalton, 1983).

Phylogenetic studies based on $16 \mathrm{~S}$ rDNA sequence analysis confirm the Antarctic methanotrophs form a distinct line of descent within the family Methylococcaceae and have the lowest DNA G $+C$ contents for any described group I methanotroph (Bowman et al., 1995). The closest relative to the isolates was the Louisiana Slope methanotrophic mytilid endosymbiont (Distel \& Cavanaugh, 1994), which has not yet been obtained in pure culture. The combination of distinctive phenotypic traits (Table 3), characteristic fatty acid profile, and phylogeny indicates that the Antarctic methanotroph represents a novel group within the family Methylococcaceae. Thus it is proposed that a new genus, Methylosphaera hansonii sp. nov., gen. nov., be created to accommodate this group of Antarctic methanotrophs. 


\section{Description of Methylosphaera gen. nov.}

Me.thy.lo.sphae'ra. Fr. n. méthyle the methyl group; Gr. fem. n. spaira a sphere; ML fem. n. Methylosphaera methyl sphere.

Spherical cells, single or in pairs, about $1.5-2 \cdot 0 \mu \mathrm{m}$ in diameter. Resting cells, including cysts and exospores, are not formed. Reproduction is by constriction. Nonmotile. Strictly aerobic. Obligate group I methanotroph. Major lipids are $16: 1 \omega 8 c, 16: 1 \omega 7 c, 16: 1 \omega 6 c$ and $16: 0$. Phylogenetically related to the family Methylococcaceae in the gamma subdivision of the Proteobacteria. Contains one species, Methylosphaera hansonii, which includes the type strain. Habitats are the chemocline zones and edge surface sediments of Antarctic marinesalinity, meromictic lakes.

\section{Description of Methylosphaera hansonii gen. nov., sp. nov.}

han.son'i.i. ML gen. n. hansonii of Hanson; named after R. S. Hanson, an American microbiologist.

Description as for the genus above plus the following. Psychrophilic growth (optimal $10-13^{\circ} \mathrm{C}$, maximum $\left.16-21^{\circ} \mathrm{C}\right)$. Requires seawater for growth. Carbon sources used include methane and methanol. Fixes atmospheric nitrogen at ambient oxygen levels. Uses nitrate, ammonia and L-glutamine as nitrogen sources. Nitrate is reduced to nitrite and a phosphohydrolase is present. RubisCO, sMMO, urease, and alkaline phosphatase are absent. DNA G $+C$ content is $43-46 \mathrm{~mol} \%$ $\left(T_{\mathrm{m}}\right)$. Type strain is ACAM 549, which was isolated from the chemocline of Ace Lake, Vestfold Hills, Antarctica.

\section{ACKNOWLEDGEMENTS}

This research and logistics for sample collection were supported through the Antarctic Science Advisory Committee (project no. 870). We thank J. Gibson and T. Ross for their helpful suggestions and comments during the preparation of this manuscript.

\section{REFERENCES}

Adamson, D. A. \& Pickard, J. (1986). Cainozoic history of the Vestfold Hills. In Antarctic Oasis, Terrestrial Environment and History of the Vestfold Hills, pp. 63-97. Edited by J. Pickard. London: Academic Press.

Ashbolt, N. J. (1990). Antarctic biotechnology-what is the potential? Aust J Biotechnol 4, 103-108.

Balch, W. E. \& Wolfe, R. S. (1976). New approach to the cultivation of methanogenic bacteria: 2-mercaptosulfonic acid (HSCoM)dependent growth of Methanobacterium ruminatium. Appl Environ Microbiol 32, 782-791.

Bowman, J. P., Jiménez, L., Rosario, I., Hazen, T. C. \& Sayler, G. S. (1993a). Characterization of the methanotrophic bacterial community present in a trichloroethylene-contaminated subsurface groundwater site. Appl Environ Microbiol 59, 2380-2387.

Bowman, J. P., Sly, L. I., Nichols, P. D., Hayward, A. C. (1993b). Revised taxonomy of the methanotrophs-description of Methylobacter gen. nov., emendation of Metbylococcus, vali- dation of Methylosinus and Methylosinus species, and a proposal that the family Methylococcaceae includes only the group I methanotrophs. Int J Syst Bacteriol 43, 735-753.

Bowman, J. P., Sly, L. I. \& Stackebrandt, E. (1995). The phylogenetic position of the family Methylococcaceae. Int J Syst Bacteriol 45, 182-185.

Brusseau, G. A., Tsien, H. C. \& Hanson, R. S. (1992). Optimization of trichloroethylene oxidation by methanotrophs and the use of a colorimetric assay to detect soluble methane monooxygenase activity. Biodegradation 1, 19-29.

Distel, D. L. \& Cavanaugh, C. M. (1994). Independent phylogenetic origins of methanotrophic and chemoautotrophic bacteria endosymbionts in marine bivalves. J Bacteriol 176, 1932-1938.

Dobson, S. J., Colwell, R. R., McMeekin, T. A. \& Franzmann, P. D. (1993). Direct sequencing of the polymerase chain reactionamplified 16S rRNA gene of Flavobacterium gondwanense sp. nov. and Flavobacterium salegens sp. nov., two new species from a hypersaline Antarctic lake. Int J Syst Bacteriol 43, 77-83.

Felsenstein, J. (1993). PHYLIP (phylogeny inference package), version $3.57 \mathrm{c}$. Seattle: University of Washington.

Franzmann, P. D. \& Dobson, S. J. (1993). The phylogeny of bacteria from a modern Antarctic refuge. Antarctic Sci 5, 267-270.

Franzmann, P. D., Skyring, G. W., Burton, H. R. \& Deprez, P. P. (1987). Sulfate reduction rates and some aspects of the limnology of four lakes and a fjord in the Vestfold Hills, Antarctica. In Biology of the Vestfold Hills, Antarctica, pp. 25-33. Edited by J. M. Ferris, H. R. Burton, G. W. Johnstone \& I. A. E. Bayly. Dordrecht: Kluwer.

Franzmann, P. D., Roberts, N. J., Mancuso, C. A., Burton, H. R. \& McMeekin, T. A. (1991). Methane production in meromictic Ace Lake, Antarctica. Hydrobiologia 210, 191-201.

Franzmann, P. D., Springer, N., Ludwig, W., de Macario, E. C. \& Rohde, M. (1992). Methanogenic archaeon from Ace Lake, Antarctica: Methanococcoides burtonii sp. nov. Syst Appl Microbiol 15, 573-581.

Galchenko, V. F. (1994). Sulfate reduction, methane production and methane oxidation in various water bodies of the Bunger Hills Oasis of Antarctica. Microbiology (English translation of Mikrobiologiya) 63, 388-396.

Gibson, J. A. E., Garrick, R. C., Franzmann, P. D., Deprez, P. P. \& Burton, H. R. (1991). Reduced sulfur gases in saline lakes of the Vestfold Hills, Antarctica. Palaeogeogr Palaeoclimat Paleoecol 84, 131-140.

Guezennec, J. \& Fiala-Medioni, A. (1996). Bacterial abundance and diversity in the Barbados Trench determined by phospholipid analysis. FEMS Microbiol Ecol 19, 83-93.

Hanson, R. S. \& Hanson, T. E. (1996). Methanotrophic bacteria. Microbiol Rev 60, 439-471.

Holmes, A. J., Owens, N. J. P. \& Murrell, J. C. (1995). Detection of novel marine methanotrophs using phylogenetic and functional gene probes after methane enrichment. Microbiology 141, 1947-1955.

Huss, V. A. R., Festl, H. \& Scleifer, K.-H. (1983). Studies on the spectrophotometric determination of DNA hybridization from renaturation rates. Syst Appl Microbiol 4, 184-192.

Koch, A. L. (1994). Growth measurement. In Methods for General and Molecular Bacteriology, pp. 248-277. Edited by R. G. E. Murray, W. A. Wood \& N.R. Krieg. Washington, DC: American Society for Microbiology.

Lees, V., Owens, N. J.P. \& Murrell, J. C. (1991). Nitrogen metabolism in marine methanotrophs. Arch Microbiol 157, $60-65$. 
Lidstrom, M. E. (1988). Isolation and characterization of marine methanotrophs. Antonie Leeuwenhoek 54, 189-199.

Mancuso, C. A., Franzmann, P. D., Burton, H. R. \& Nichols, P. D. (1991). Microbial community structure and biomass estimates of a methanogenic Antarctic lake ecosystem as determined by phospholipid analyses. Microb Ecol 19, 73-95.

Marmur, J. \& Doty, P. (1962). Determination of the base composition of deoxyribonucleic acid from its thermal denaturation temperature. J Mol Biol 5, 109-118.

Murrell, J. C. \& Dalton, H. (1983). Nitrogen fixation in obligate methanotrophs. J Gen Microbiol 129, 1197-1206.

Nichols, P. D., Smith, G. A., Antworth, C. P., Hanson, R. S. \& White, D. C. (1985). Phospholipid and lipopolysaccharide normal and hydroxy fatty acids as potential signatures for methaneoxidizing bacteria. FEMS Microbiol Ecol 32, 327-335.

Nichols, P. D., Guckert, J. B. \& White, D. C. (1986). Determination of monounsaturated bond position and geometry for microbial monocultures and complex consortia by capillary GC-MS of their dimethyldisulfide adducts. J Microbiol Methods 5, 49-55.

Nichols, D. S., Nichols, P. D. \& McMeekin, T. A. (1993). Polyunsaturated fatty acids in Antarctic bacteria. Antarctic Sci 5, 149-160.

Omelchenko, M. V., Vasileva, L. V., Zavarzin, G. A., Saveleva,
N. D., Lysenko, A. M., Mityushina, L. L., Khmelenina, V. N. \& Trotsenko, Y. A. (1996). A novel psychrophilic methanotroph of the genus Metbylobacter. Microbiology (English translation of Mikrobiologiya) 65, 339-343.

Sieburth, J. M., Johnson, P. W., Eberhardt, M. A., Sieracki, M. E., Lidstrom, M. E. \& Laux, D. (1987). The first methane-oxidizing bacterium from the upper mixing layer of the deep ocean: Methylomonas pelagica sp. nov. Curr Microbiol 14, 285-293.

Sly, L. I., Blackall, L. L., Kraat, P. C., Tian-Shen, T. \& Sangkhobol, V. (1986). The use of second derivative plots for the determination of mol \% guanine plus cytosine of DNA by the thermal denaturation method. J Microbiol Methods 5, 139-156.

Takeda, K. (1988). Characteristics of a nitrogen-fixing methanotroph, Methylocystis T-1. Antonie Leeuwenboek 54, 521-534.

Vela, G. R. \& Wyss, O. (1964). Improved stain for the visualization of Azotobacter encystment. J Bacteriol 87, 476-477.

Ward, B. B., Kilpatrick, K. A., Novell, P. C. \& Scranton, M. I. (1987). Methane oxidation and methane fluxes in the ocean surface layer and deep anoxic waters. Nature 327, 226-229.

Received 11 September 1996; revised 18 November 1996; accepted 25 November 1996. 